\title{
THE ANDRELÂNDIA BASIN, A NEOPROTEROZOIC INTRAPLATE CONTINENTAL MARGIN, SOUTHERN BRASÍLIA BELT, BRAZIL
}

\author{
FABIO VITO PENTAGNA PACIULLO, ANDRÉ RIBEIRO, RENATO RODOLFO ANDREIS \\ AND RUDOLPH ALLARD JOHANNES TROUW.
}

\begin{abstract}
The Andrelândia succession comprises six lithofacies associations, from base to top, represented by: A1- paragneiss; A2paragneiss, quartzite and schist; A3- quartzite; A4- grey phyllite/schist; A5- biotite schist/gneiss; A6- paragneiss, metachert and calc-silicate rocks. Amphibolite bodies are common in the A1, A2 and A6 associations. They represent continental and oceanic tholeiitic magmatism generated during the basin evolution. The vertical and horizontal distribution of these lithofacies suggest transgressive and regressive depositional systems of common intraplate continental margin paleoenvironments, probably including continental (A1), coastal plain-platform (A2, A3, A4, A6), submarine fan and basin plain deposits (A5,A6). The lithofacies associations and the mafic magmatism also reflect different stages of basin evolution from rifting (A1) to proto-oceanic (A2, A6) and mature continental margin stages (A3, A4, A5, A6). This continental margin had its paleocoastline oriented NW-SE and depocenter to WSW as indicated by the regional distribution of the quartzitic and pelitic lithofacies. The basin opening is related to a world-wide taphrogenic event that started at circa 1,000 Ma. The Andrelândia Basin comprises the intraplate continental margins between the São Francisco plate and the Paraná Block. The basin closure took place in two subsequent collisional stages during the Brasiliano Orogeny that resulted in the Brasília Belt and the Central Segment of the Ribeira Belt.
\end{abstract}

Keywords: Neoproterozoic basin; intraplate continental margin; southern São Francisco Craton

\section{INTRODUCTION}

Mobile belts usually comprise deformed intraplate continental margins. Therefore, allostratigraphy analysis is an important tool to interpret sedimentary events in such belts where deformation and metamorphism are sufficiently well understood to permit recognition of the sedimentary successions. This approach has been applied to the interference zone between the Neoproterozoic Brasília and Ribeira belts (Ribeiro et al. 1995, Paciullo et al. 1998) at the southern border of the São Francisco Craton, Minas Gerais State (Fig. 1, inset). In this region, three superposed Proterozoic basins developed on a basement of Paleoproterozoic and Archean greenstone belts and gneiss complexes. The Mesoproterozoic São João del Rei and Carandai basins are intracratonic and their sequences crop out only in the foreland areas on the São Francisco Craton. The Neoproterozoic Andrelândia basin is an intraplate continental margin (in the sense of Ingersoll \& Busby 1995) developed at the border of the São Francisco paleocontinent. The basin successions extend far away from the foreland into the internal zones of the mobile belt. They were deformed during the Braziliano Orogeny (700-450 Ma) in a ductile nappe system with top to east tectonic transport (Campos Neto and Caby 1999). The associated metamorphism varies from middle greenschist to granulite facies.

\section{THE ANDRELÂNDIA BASIN Lithofacies association} and distribution The lithofacies associations and their vertical and horizontal distribution record distinct paleoenvironments and the approximate extension of the Andrelândia basin. From base to top these units are (Fig. 2): A1- paragneiss; A2- paragneiss, quartzite and schist; A3- quartzite; A4- gray phyllite/schist; A5- biotite schist/gneiss; A6- paragneiss, metachert and calc-silicate rocks. Amphibolite bodies are common in the $\mathrm{A} 1, \mathrm{~A} 2$ and $\mathrm{A} 6$ associations.

The A1 lithofacies association is the basal unit in almost all sectors of the Andrelândia basin (Figs. 1 and 3). It comprises massive or layered biotite gneisses, which appear as thin to medium thick tabular beds building up decametric successions. They may contain quartz, feldspar and quartz-feldspathic fragments and are interpreted as feldspathic sandstones. However, some felsic layers could also represent contemporaneous felsic magmatism. Geochemical diagrams indicate an acid to intermediate igneous source (Paciullo 1997). The A2 lithofacies association reaches a few hundred meters in thickness. It comprises the paragneiss facies (A1) and thin to very thick quartzite and schist intercalations. Locally thin tabular beds of Mn-garnet quartzite and meter thick marble bodies also occur. The schistquartzite-paragneiss succession is interpreted as parasequence and the stacking pattern suggests a retrogradational parasequence set. The A3 lithofacies association, up to 60 meters thick, is constituted of thin to thick tabular beds of micaceous quartzites and thin schist layers and laminae, also defining parasequence patterns. The association is interpreted as an aggradational parasequence set. Cross bedding and hummocky structures are locally preserved. Scarce basal quartzose metaconglomerate lenses occur in the Carrancas area and the finer and thinner facies predominates to the southwest (Luminárias area) indicating the direction of basin deepening. The A4 lithofacies association comprises an up to 100 meters thick pelitic succession of gray phyllites and schists with minor quartzite intercalations. To the north, the A4 pelites cover abruptly the A3 quartzites, the A1 paragneisses, the basement and units of the Carandaí basin. To the south they intercalate with the distal A3 quartzites (Fig. 3A). The A5 lithofacies association is represented by an at least 200 meters thick succession of massive or thin-bedded feldspathic biotite phyllites and schists. The basal facies locally contains dispersed pebbles, blocky dropstones and diamictite bodies, including vein quartz, granitoid and calc-silicate fragments. The upper facies includes scarce carbonate beds. The lithology itself and the bedding features suggest feldspathic siltites and fine sandstones of turbiditic character as protoliths. To the south, basinward, the biotite schists grade into paragneiss of the A6 association. To the north, in the foreland area, they cover the older Andrelândia, Carandaí and basement units. In the São Tomé das Letras area a pebbly thin-bedded facies covers an erosional surface developed on A3 and A4 associations suggesting an intrabasinal sequence boundary. The A6 lithofacies association, at least 500 meters thick, is dominated by massive or thin-bedded paragneiss successions with thin tabular metachert and calc-silicate rock intercalations. In the Andrelândia area an up to 50 meters thick quartzite at the base of the A6 association is interpreted as a sandy turbiditic lobe.

Amphibolites occur as lenticular or tabular bodies parallel to bedding, a few decimeters up to 50 meters in thickness, intercalated in the A1, A2 and A6 associations. Small retro-eclogite lenses appear in the A6 association where it reaches upper amphibolite and granulite metamorphic facies. These mafic rocks are subalkaline tholeiitic metabasalts of continental or oceanic geochemical affinities (Gonçalves and Figueiredo 1992, Paciullo 1997). Ultramafic rocks such as peridotite, pyroxenite, serpentinite, chlorite and talc schists occur at the base of some thrust sheets. Geochemical data suggest that part of the ultramafic rocks represent tholeiitic cumulates (Almeida, 1992) probably related to the same magmatism that generated the amphibolite protoliths.

Depositional events The A1 lithofacies association probably represents the rift phase of basin evolution. The paragneiss constitutes the floor of almost the whole basin suggesting continental paleoenvironments, probably amalgamated sandy aprons and wide sandy braided plains. The tholeiitic amphibolites and some of the felsic layers record the associated faulting and magmatism. The A2 association records the proto-oceanic phase. A marine incursion into the basin generated a coastal plain (schist-paragneiss) and a platform (schist-quartzite) in an overall transgressive event. At that time magmatism was still active as indicated by the amphibolite intercalations. The A3 association constitutes an aggradational parasequence set developed on a stable platform during the mature continental margin phase. The deposition of the A4 pelites on all older 


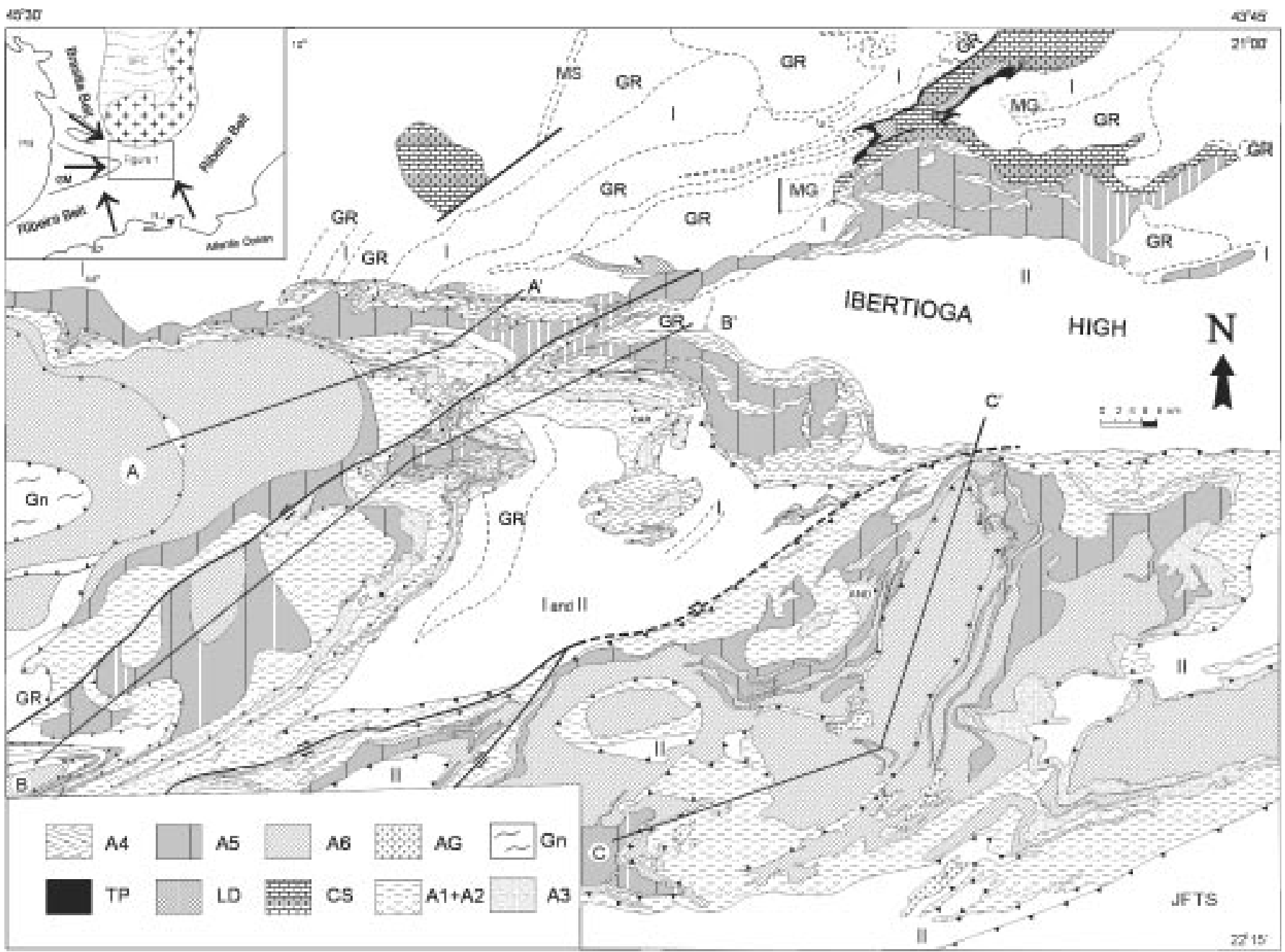

Figure 1. Geological map of the interference zone between the Brasília and Ribeira belts, southern Minas Gerais State. Basement units- Archean: greenstone belts (I) and Mantiqueira Complex (II); Paleoproterozoic: Minas Supergroup (MS) and intrusive igneous rocks (GR- metagranitoid and MG- metagabroic rocks). Meso-Neoproterozoic units: São João del Rei basin- Tiradentes platform quartzites (TP) and metapelites, quartzites and metaconglomerates of the Lenheiro Delta (LD). Metapelites and limestones of the Carandaí basin (CB). Andrelândia basin lithofacies associations: A1 and A2-paragneiss, quartzite, schist and amphibolite; A3- quartzite; A4- grey phyllite/schist; A5-biotite schist/gneiss; A6- paragneiss, metachert, calc-silicate rocks and amphibolites. AG-Anatectic granites. Gn-Guaxupé nappe. JFTS-Juiz de Fora thrust system. Cities: LU-Luminárias, CAR-Carrancas, STL-São Tomé das Letras, AND-Andrelândia. AA', $B B^{\prime}$ and CC' - geological sections. Inset map: area localization: GM-Guaxupé Massif; SFC-São Francisco Craton: crosses - basement; wavy lines - cover; PB-Paraná Basin; RJ-Rio de Janeiro. Arrows - main tectonic transport direction during the Brasiliano Orogeny.

units, including the basement, registers the maximum flooding of the transgressive event. The A5 association comprises regressive and transgressive deposits related to glacial and post-glacial periods indicating important changes in the paleoclimate conditions. The complete succession is interpreted as regressive at the base, comprising glacio-marine pebbly thin-bedded turbidites (allochthonous domains) and scarce dropstones and diamictite (autochthonous domain; Fig. 1). Upward it passes to post-glacial transgressive pelites that overlap all older units in both autochthonous and allochthonous domains. The basal facies can be correlated with other glaciogenic deposits around and on the São Francisco Craton (e.g. Macaúbas, Ibiá, Bebedouro and Jequitaí Groups). When compared with other worldwide Precambrian glaciations (Eyles and Eyles 1992) this one is most likely related to the Late Riphean (980-850 Ma) glaciation. The A6 association comprises pelagic, hemipelagic and turbiditic deposits of the distal and deep sectors of the basin developed after the proto-oceanic stage was achieved. The presence of tholeiitic E-MORB amphibolites, metachert and calc-silicate intercalations indicates an ocean floor paleoenvironment. The distribution of the lithofacies associations indicates basin depocenters to the west, southwest and south, where the A6 association is the dominant unit (Figs. 1 and 3A).

BASIN CLOSURE The Andrelândia basin was closed during the Brasiliano Orogeny, in the time interval between 630 and $560 \mathrm{Ma}$. The basin closure can be related to the almost perpendicular and

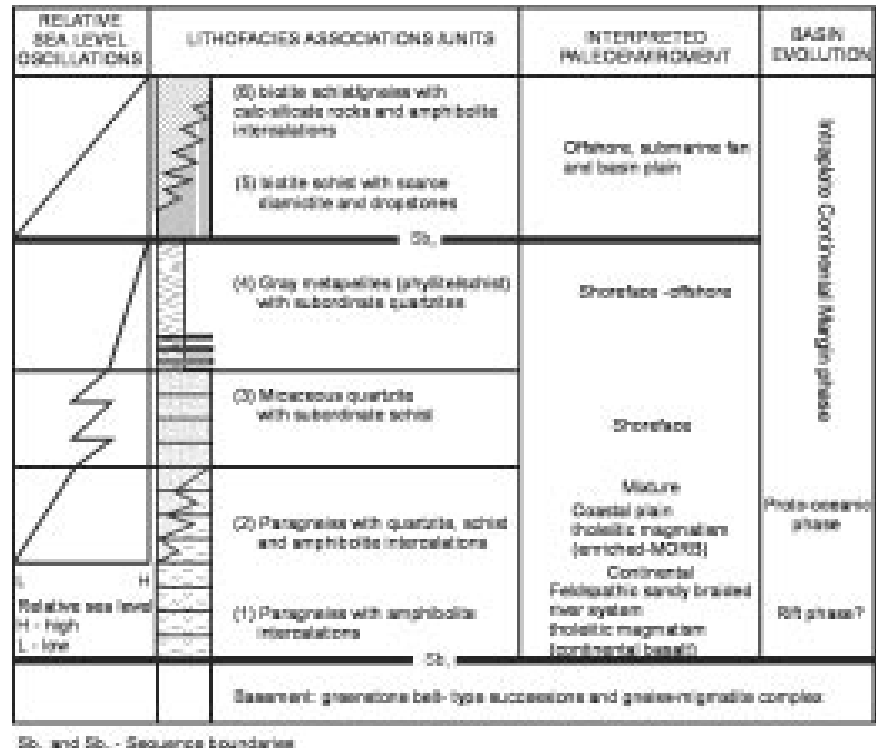

Figure 2. Stratigraphic column, interpreted paleoenvironments and stages of Andrelândia Basin evolution. 

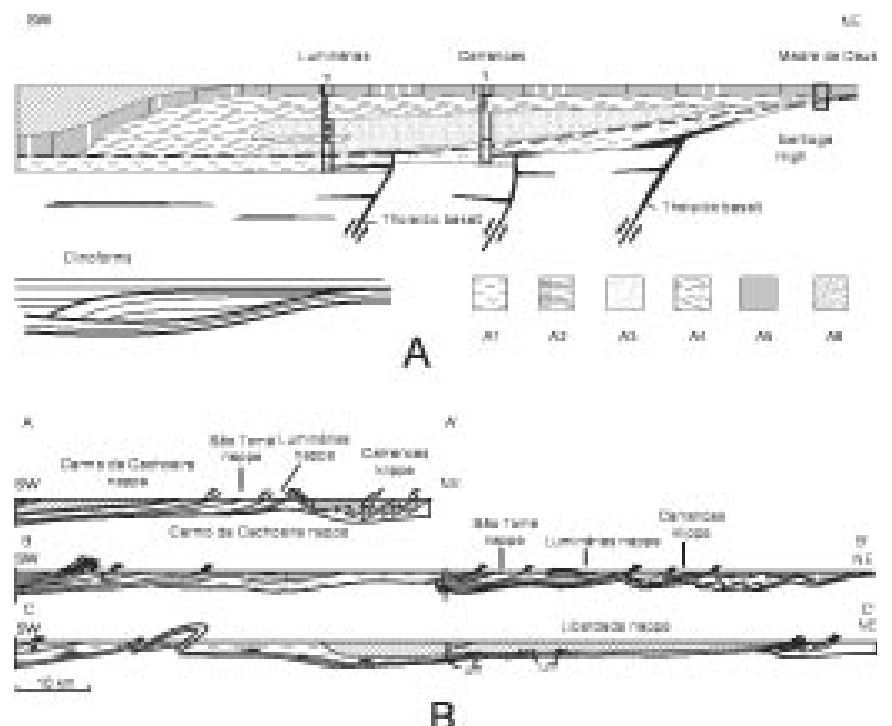

B

Figure 3. A - The Andrelândia intraplate continental margin basin interpreted from the vertical and horizontal lithofacies association distribution. Alparagneisses; A2- paragneisses, quartzites, schists; A3- quartzite; A4- gray phyllite/schist; A5-biotite schist/gneiss; A6- paragneiss, metachert and calcsilicate rocks. See section BB' in Fig. 4 for present structural architecture. BGeological sections.

subsequent continental collisions that generated the southern part of the Brasília Belt and the central segment of the Ribeira Belt.

Southern Brasilia Belt This part of the Brasilia belt evolved from a WSW subduction to a collision between the São Francisco paleocontinent and the Paraná block. Arc granitoids, located in the Guaxupé Massif yielded U/Pb ages between 670 and $620 \mathrm{Ma}$ (Figueiredo and Campos Neto 1994). The main collisional phase produced top to the east tectonic transport in the order of hundreds of kilometres (Fig. 3B; Campos Neto and Caby 1999). It was responsible for the main deformational phases and the relative high-pressure metamorphism in the Andrelândia successions. Retro-eclogites of the A6 lithofacies association yielded Sm/Nd ages of approximately 604 Ma for the metamorphism (Trouw and Pankhurst 1993).

Central Segment of the Ribeira Belt This part of the belt evolved from southeastward subduction to a collision between the São Francisco paleocontinent and the Serra do Mar microplate (Campos Neto and Figueiredo 1995, Heilbron et al. 1999). Arc granitoids located in the Serra do Mar microplate yielded U/Pb ages of $630 \mathrm{Ma}$ (Tupinambá et al. 1998) indicating some overlap with the arc activity in the Paraná block. Two thermotectonic events record the collisional stage in the Andrelândia successions. The first event generated top to NW tectonic transport and the second one generated subvertical dextral NE-SW shear zones. The associated metamorphism in both events was of medium pressure type. U/Pb geochronology yielded ages of 590-565 Ma for the former event and 535-520 Ma for the latter (Heilbron et al. 1995, Machado et al. 1996). The superposition of structures and metamorphism related to the Brasilia and Ribeira belts generated the interference zone between the two belts in the present area (Fig. 1).

CONCLUSIONS The age of the basin opening is not well established. The available geochronological data indicate that the basement rocks are older than $1800 \mathrm{Ma}$ (Avila et al. 1998). Sm/Nd $\mathrm{T}_{\mathrm{DM}}$ age values of 1054 and $1184 \mathrm{Ma}$ from Andrelândia amphibolites are interpreted as the minimum ages for basin opening (Ribeiro et al. 1995). The basin development can, therefore, be related to the breakup of the supposed Rodinia supercontinent. This process may have generated a triple junction with NW-SE and NE-SW troughs, which evolved to the intraplate continental margin basins. The successions of these basins presently constitute the mobile belts surrounding the São Francisco Craton. The Andrelândia succession corresponds to the part of this system localized at the southern border of the craton.

Acknowledgments To two anonymous referees of RBG for the critical review of the manuscript.

\section{References}

Almeida S. 1992. Petrografia e Geoquímica de rochas ultramáficas na região de Liberdade e Carrancas, Minas Gerais. Tese de Mestrado, IGEO-UFRJ, Rio de Janeiro, 1992, $166 \mathrm{p}$.

Avila C.A., Moura C.A.V., Valença J.G., Ribeiro A., Paciullo F.V.P. 1998. Idades Pb-Pb em zircões de corpos plutônicos da região de São João del Rei, borda sul do Cráton do São Francisco, sul de Minas Gerais. In: Cong. Bras. Geol., 40, Belo Horizonte, MG. Anais ..., Belo Horizonte, SBG, p. 34.

Ingersoll R. V. and Busby C. J. 1995. Tectonics of Sedimentary Basins. In: Busby C.J. and Ingersoll R.V. eds., Tectonics of Sedimentary Basins, Blackwell Science, p. 1-51.

Campos Neto M. C. and Caby R. 1999. Neoproterozoic high-pressure metamorphism and tectonic constraint from nappe system south of the São Francisco Craton, southeast tectonic constraint from nappe system sout
Brazil. Precambrian Research, 97:3-6.

Campos Neto M. C. and Figueiredo M. C. H. 1995. The Rio Doce Orogeny, Southeastern Brazil. J.S.A. Earth Sciences, 8:143-162.

Eyles N. and Eyles C. H. 1992. Glacial Depositional Systems. In: Walker R. G. and James N. P. eds., Facies Models. Response to Sea Level Change.. Geol. Ass. of Canada, p.73-100.

Figueiredo M. C. and Campos Neto M. C. 1994. O arco magmático cálcio-alclino de altoK da Microplaca Apiaí-Guaxupé. In: Congr. Bras. Geol., 38, Balneário Camboriú, SC, 1994. Bol. Res Exp...., Balneário Camboriú, SBG, v.1, p. 620-621.

Gonçalves M. L. and Figueiredo M.C.H. 1992. Geoquímica dos anfibolitos de Santana do Garambéu, MG: implicações sobre a evolução do Grupo Andrelândia. Geochim. Brasil. 6:127-140.

Heilbron M., Valeriano C.M., Valladares C.S., Machado N. 1995. A orogênese brasilian no segmento central da Faixa Ribeira, Brasil, Revista Brasileira de Geociências, 25:249-266.

Heilbron M., Mohriak W., Valeriano C.M., Milani E., Almeida J.C.H., Tupinambá M. 2000. From Collision to Extension: The Roots of the Southeastern Continental Margin of Brazil. In: Mohriak W. and Manik T. eds. Atlantic rifts and continental margins, AGU, Washington, DC, Geophysical Monograph 115:1-32.
Machado N., Valladares C.S., Heilbron M., Valeriano C.M. 1996. U/Pb Geochronology of Central Ribeira Belt, Precambrian Research, 79:347-361.

Paciullo F.V.P. 1997. A sequência deposicional Andrelândia, Unpublished Thesis,Instituto de Geociências da Universidade Federal do Rio de Janeiro, Rio de Janeiro, 245 pp. Paciullo F.V.P., Ribeiro A., Andreis R.R., Trouw R.A.J. 1998. Sedimentary, igneous and thermo-tectonic events in the folded belts at the southern border of the São Francisco craton, In: International Conference On Precambrian And Craton Tectonics, 14th International Conference On Basement Tectonics, Ouro Preto, Brazil. Abstracts...Ouro Prêto, p. 68-69.

Ribeiro A., Trouw R.A.J., Paciullo F.V.P., Andreis R.R., Valença J.G. 1995. Evolução das bacias proterozóicas e termo-tectonismo brasiliano na margem sul do Cráton do São Francisco, Revista Brasileira de Geociências, 25:235-248.

Trouw R. A. J. and Pankhurst R. J. 1993. Idades radiométricas ao sul do Cráton do São Francisco: região da Folha Barbacena, Minas Gerais. In : Simp. Cráton Do São Francisco, 2, Salvador, 1993. Anais..., Salvador, p.260-262.

Tupinambá M., Teixeira W., Heilbron M. 1998. The Pan-African/Brasiliano Arc-related Magmatism at the Costeiro Domain of the Ribeira belt, Southeastern Brazil. In: Abstracts Of The International Conference On Precambrian And Craton Tectonics, 14th International Conference On Basement Tectonics. Ouro Preto, Brazil. Abstracts...Ouro Prêto, p. 12-14 